\title{
Preface for special series on the Third International Cough Conference
}

Cough is the most common complaints for patients who seek medical attention worldwide (1). Chronic cough of more than 8 weeks' duration exerts serious impact on quality of life, and causes huge economic burden (2). A great progress had been made in the research field of cough in recent decades, including mechanism, diagnosis and treatment of chronic cough. The International Cough Conference has been held in China for three times from 2013 to 2019 (3), providing an important communication platform for scientists, physicians on cough following London Cough Symposium (4), America Cough Conference (5).

The Third International Cough Conference (3rd ICC) was held successfully on November 8-10, 2019, in Guangzhou (3), which featured nine high-standard sessions touching on the developments in cough field delivered by world-leaders, including the epidemiology and pathogenesis, cough hypersensitivity, evaluation of chronic cough, diagnosis and therapies for common and uncommon causes of chronic cough, future direction of chronic cough research. The Fournal of Thoracic Disease (FTD) invites the conference speakers to submit reviews based on their topics for the 3rd ICC. Many of the specialists have been too busy with their clinical tasks to finish the manuscripts on time due to COVID-19 pandemic, and therefore the special issue on 3rd ICC will be published in two separate issues. With gratitude to the hard work of authors, the first series now appear in September.

Cough hypersensitivity, an important and common physiopathological feature in patients with chronic cough is a big challenge to clinicians (6,7). Understanding the mechanism of cough hypersensitivity will shed light on the development of new drugs related to cough. In this issue, we publish the review "Peripheral and central mechanism of cough hypersensitivity" by Dr. Stuart B. Mazzone. There are numerous epidemiological surveys on chronic cough, however, the data from Asian countries is limited (8,9). The review "Chronic congh in Korea" by Dr. Woo-Jung Song. will add to information regarding prevalence, demographics, risk factors of chronic cough. Cough frequency as an objective measure has become a primary endpoint in clinical trials of cough along with the development of cough monitor (10). Dr. Surinder S. Birring systematically reviews the present and future of cough counting tools. Should chest CT and bronchoscopy be used as routine investigations for patients with chronic cough? Prof. Li Yu and Prof. Lorcan McGarvey made their arguments respectively. Eosinophilic bronchitis is one of the most common causes of chronic cough, but seems an independent condition rather than an early stage of asthma or COPD (11), and it is not certain how long the eosinophilic bronchitis should be treated with inhaled corticosteroids $(12,13)$. Prof. Akio Niimi discussed this topic in this issue. Please read the reviews in special series of the 3rd ICC for more details.

\section{Acknowledgments}

Funding: This work was supported by the Incubative Project for Innovation Team of GMU (2017-159), the National Science Foundation of China (81770098).

\section{Footnote}

Provenance and Peer Review: This article was commissioned by the editorial office, fournal of Thoracic Disease for the series "3rd International Cough Conference". The article did not undergo external peer review.

Conflicts of Interest: The author has completed the ICMJE uniform disclosure form (available at http://dx.doi.org/10.21037/ jtd-2020-icc-preface). The series "3rd International Cough Conference" was commissioned by the editorial office without any funding or sponsorship. Prof. KL served as the unpaid Guest Editors of the series and serves as an unpaid editorial board member of Journal of Thoracic Disease. The author has no other conflicts of interest to declare.

Ethical Statement: The author is accountable for all aspects of the work in ensuring that questions related to the accuracy or integrity of any part of the work are appropriately investigated and resolved.

Open Access Statement: This is an Open Access article distributed in accordance with the Creative Commons Attribution- 
NonCommercial-NoDerivs 4.0 International License (CC BY-NC-ND 4.0), which permits the non-commercial replication and distribution of the article with the strict proviso that no changes or edits are made and the original work is properly cited (including links to both the formal publication through the relevant DOI and the license). See: https://creativecommons.org/ licenses/by-nc-nd/4.0/.

\section{References}

1. Song WJ, Chang YS, Faruqi S, et al. The global epidemiology of chronic cough in adults: a systematic review and meta-analysis. Eur Respir J 2015;45:1479-81.

2. Li B, Lai K, Wang F, et al. Quality-of-life questionnaire in patients with chronic cough. Int J Respir 2011:326-8.

3. Luo $\mathrm{W}, \mathrm{Xu} \mathrm{T}$, Chen $\mathrm{Y}$, et al. Global specialists talk on latest advances in cough studies: a close-up of the Third International Cough Conference in Guangzhou, China. J Thorac Dis 2019;11:5712-7.

4. Chung KF, McGarvey L, Mazzone SB. Progress in cough hypersensitivity at the Tenth London International Cough Symposium 2018 (10th LICS 2018). Pulm Pharmacol Ther 2019;59:101850.

5. Dicpinigaitis PV. The Second American Cough Conference. Lung 2010;188 Suppl 1:S1-2.

6. Morice AH, Millqvist E, Belvisi MG, et al. Expert opinion on the cough hypersensitivity syndrome in respiratory medicine. Eur Respir J 2014;44:1132-48.

7. Song WJ, Morice AH. Cough hypersensitivity syndrome: a few more steps forward. Allergy Asthma Immunol Res 2017;9:394-402.

8. Lai K, Pan J, Chen R, et al. Epidemiology of cough in relation to China. Cough 2013;9:18.

9. Song WJ, Faruqi S, Klaewsongkram J, et al. Chronic cough: an Asian perspective. Part 1: Epidemiology. Asia Pac Allergy 2015;5:136-44.

10. Cho PSP, Birring SS, Fletcher HV, et al. Methods of cough assessment. J Allergy Clin Immunol Pract 2019;7:1715-23.

11. Lai K, Liu B, Xu D, et al. Will nonasthmatic eosinophilic bronchitis develop into chronic airway obstruction?: a prospective, observational study. Chest 2015;148:887-94.

12. Lai K, Chen R, Peng W, et al. Non-asthmatic eosinophilic bronchitis and its relationship with asthma. Pulm Pharmacol Ther 2017;47:66-71.

13. Zhan W, Tang J, Chen X, et al. Duration of treatment with inhaled corticosteroids in nonasthmatic eosinophilic bronchitis: a randomized open label trial. Ther Adv Respir Dis 2019;13:1753466619891520.

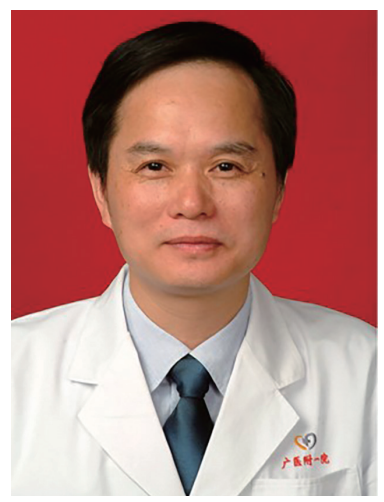

Kefang Lai

Kefang Lai State Key Laboratory of Respiratory Disease, National Clinical Research Center for Respiratory Disease, Guangzhou Institute of Respiratory Health, the First Affiliated Hospital of Guangzhou Medical University, Guangzhou, China. (Email: klai@163.com) Submitted Sep 14, 2020. Accepted for publication Sep 20, 2020. doi: $10.21037 /$ jtd-2020-icc-preface

Cite this article as: Lai K. Preface for special series on the Third International Cough Conference. J Thorac Dis 2020;12(9):5177-5178. doi: 10.21037/jtd-2020-icc-preface
View this article at: http://dx.doi.org/10.21037/jtd-2020-icc-preface 